\title{
PREDIKSI FRAUD PADA LAPORAN KEUANGAN DENGAN FRAUD DIAMOND MENGGUNAKAN BENISH M-MODEL
}

\author{
Meiliana Jaunanda ${ }^{1}$, Sukrisno Agoes ${ }^{2}$ \\ ${ }^{1}$ Program Studi Magister Akuntansi, Universitas Tarumanagara \\ Email : meilianajaunanda@gmail.com \\ ${ }^{2}$ Fakultas Ekonomi, Universitas Tarumanagara Jakarta
}

Masuk : 10-04-2019, revisi: 10-10-2019, diterima untuk diterbitkan : 30-10-2019

\begin{abstract}
ABSTRAK
Tujuan dari penelitian ini adalah untuk mengetahui apakah financial stability, external pressure, nature of industry, ineffective monitoring, rationalization dan capability dapat mengukur fraud diamond, baik secara parsial maupun secara simultan. Metode pengujian yang digunakan dalam penelitian ini adalah regresi linier. Subjek dari penelitian adalah perusahaan manufaktur yang termasuk dalam sektor industri dasar dan kimia yang terdaftar di Bursa Efek Indonesia periode 2014-2016. Data yang digunakan dalam penelitian ini adalah data sekunder seperti laporan keuangan. Hasil dari penelitian ini adalah (1) financial stability yang diproksikan dengan Agrow secara parsial memiliki pengaruh signifikan terhadap fraudulent financial statement. (2) rationalization yang diproksikan dengan TATA secara parsial memiliki pengaruh signifikan terhadap fraudulent financial statement. (3) financial stability, external pressure, nature of industry, ineffective monitoring, rationalization dan capability secara simultan memiliki pengaruh yang signifikan terhadap return saham.
\end{abstract}

Kata Kunci : Kinerja Keuangan, Efisiensi Operasi, Firm Growth, Leverage, Likuiditas, Firm Size

\begin{abstract}
The objective of this research is to examine the effect of financial stability, external pressure, nature of industry, ineffective monitoring, rationalization and capability both partially and simultaneously towards fraud diamond, The testing method used in this research is linear regression. The subject of this study are manufacturing companies which were listed in Bursa Efek Indonesia in the period 2014-2016. The samples are 31 companies determined based on purposive sampling. The data used in this study are secondary data such as financial statements. The results of this study are (1) financial stability is proxied by Agrow partially have a significant effect towards fraudulent financial statement. (2) rationalization is proxied by TATA partially have a significant effect towards fraudulent financial statement. (3) financial stability, external pressure, nature of industry, ineffective monitoring, rationalization and capability simultaneously have a significant effect towards fraudulent financial statement
\end{abstract}

Keywords : Financial performance, Efficiency Operation, Firm Growth, Leverage, Liquidity, Firm Size.

\section{PENDAHULUAN}

\section{Latar Belakang}

Banyaknya kasus kecurangan dalam laporan keuangan, American Institute Certified Public Accountant (AICPA) menerbitkan Statement of Auditing Standards No. 99 (SAS No. 99) mengenai Consideration of Fraud in a Financial Statement Audit pada Oktober 2002. (Skousen, 2009). SAS No 99 dikeluarkan terkait skandal Enron dan WorldCom dan dibentuk untuk memberikan panduan bagi para auditor mengenai bagaimana cara mengidentifikasi fraud dalam laporan keuangan. Contohnya memberikan pemahaman bagi auditor untuk memperhatikan area yang beresiko seperti pengakuan pendapatan dan kontrol yang tidak dijalankan oleh manajemen.

SAS no 99 diadopsi berdasarkan teori fraud triangle D. R. Cressey tahun 1953. (Wolfe \& Hermanson, 2014) bahwa fraud triangle dapat ditingkatkan menjadi lebih baik dalam hal 
pencegahan serta deteksi dalam fraud dengan mempertimbangkan 4 elemen yaitu incentive, opportunity, rationalization dan capability. Sifat dan kemampuan seseorang memainkan peran utama dalam melakukan fraud.

Fraud yang bernilai besar biasanya terjadi dikarenakan seseorang yang memiliki kemampuan yang tepat dan kedudukan yang baik didalam suatu organisasi. Peluang yang tersedia menjadi pintu masuk utnuk melakukan penipuan, insentif dan rasionalisasi dapat menarik orang ke arah itu. Tetapi orang itu harus memiliki kemampuan untuk mengenali pintu yang terbuka sebagai peluang dan memanfaatkannya dengan berjalan tidak hanya sekali, tetapi berulang kali. (Wolfe \& Hermanson, 2014)

\section{Kajian Teori}

Teori signaling menyatakan bahwa perusahaan yang berkualitas baik dengan sengaja akan memberikan sinyal pada pasar yang berupa informasi, dengan demikian pasar diharapkan dapat membedakan perusahaan yang berkualitas baik dan buruk. Jika informasi tersebut memberikan sinyal yang baik maka diharapkan pasar akan bereaksi pada waktu pengumuman tersebut diterima oleh pasar yang reaksinya akan terlihat dari adanya perubahan tingkat penjualan saham (Artista, 2012). Pelaporan keuangan yang menyesatkan merupakan kesalahan penyajian suatu pengungkapan dengan tujuan untuk menipu para pengguna laporan keuangan.

Pelaporan keuangan yang mengandung kecurangan biasanya dilakukan dengan cara sebagai berikut: 1. Memanipulasi, pemalsuan, atau mengubah catatan akutansi atau dokumen pendukung yang menjadi dasar penyusunan laporan keuangan. 2. Kesalahan pengungkapan, atau penghilangan secara sengaja peristiwa transaksi, atau informasi signifikan lain dalam laporan keuangan. 3. Kesalahan yang disengaja atas penerapan prinsip akutansi khususnya yang berkaitan dengan jumlah, klasifikasi, penyajian atau pengungkapan.

Financial stability merupakan kondisi keuangan dikatakan stabil apabila perusahaan dapat memenuhi segala kebutuhan rutin saat ini, yang akan datang, dan sifatnya mendadak sekalipun. Ketika suatu perusahaan berada dalam kondisi stabil maka nilai perusahaan akan naik dalam pandangan investor, kreditur dan publik.

External Pressure merupakan tekanan yang berlebihan bagi manajemen untuk memenuhi persyaratan atau harapan dari pihak ketiga. Variabel ini dapat diukur dengan membandingkan kewajiban (hutang) terhadap total asset.

Nature of Industry merupakan suatu keadaan yang dapat dikatakan ideal pada perusahaan berdasarkan industrinya. Perusahaan memiliki kebijakan tertentu menentukan bersarnya saldo berdasarkan estimasi terhadap akun-akun tertentu pada laporan keuangan seperti akun piutang tak tertagih dan akun persediaan.

Effective Monitoring diukur ketika Direksi atau Komisaris yang memegang saham dalam perusahaan tersebut, dengan attitude toward money yang dimiliki, akan berupaya untuk memastikan bahwa tidak akan ada tindakan yang dapat berdampak buruk pada kondisi finansial perusahaan, yang juga akan mempengaruhi kondisi finansial mereka.

Rasionalisasi merupakan total akrual besaran yang telah ditentukan oleh manajer sehingga dapat memberikan peluang untuk melakukan manipulasi. tingkat akrual perusahaan akan beragam tergantung dari keputusan manajemen terkait kebijakan tertentu. Hal itu karena akrual adalah 
wakil dari keputusan yang telah dibuat oleh manajemen dan memberikan wawasan atau informasi tentang rasionalisasi laporan keuangan perusahaan.

Capability diukur dengan indicator Pertama, kedudukan seseorang memberikan peluang untuk melakukan berbagai cara dalam melaksanakanpenipuan. Kedua, seseorang mampu melakukan penipuan cukup cerdas untuk memahami kelemahan internal kontrol dengan menggunakan posisi, fungsi, atau wewenang. Ketiga, seseorang memiliki keyakinan besar bahwa dia tidak akan terdeteksi.

Kerangka pemikiran dalam penelitian ini disajikan dalam gambar berikut ini:

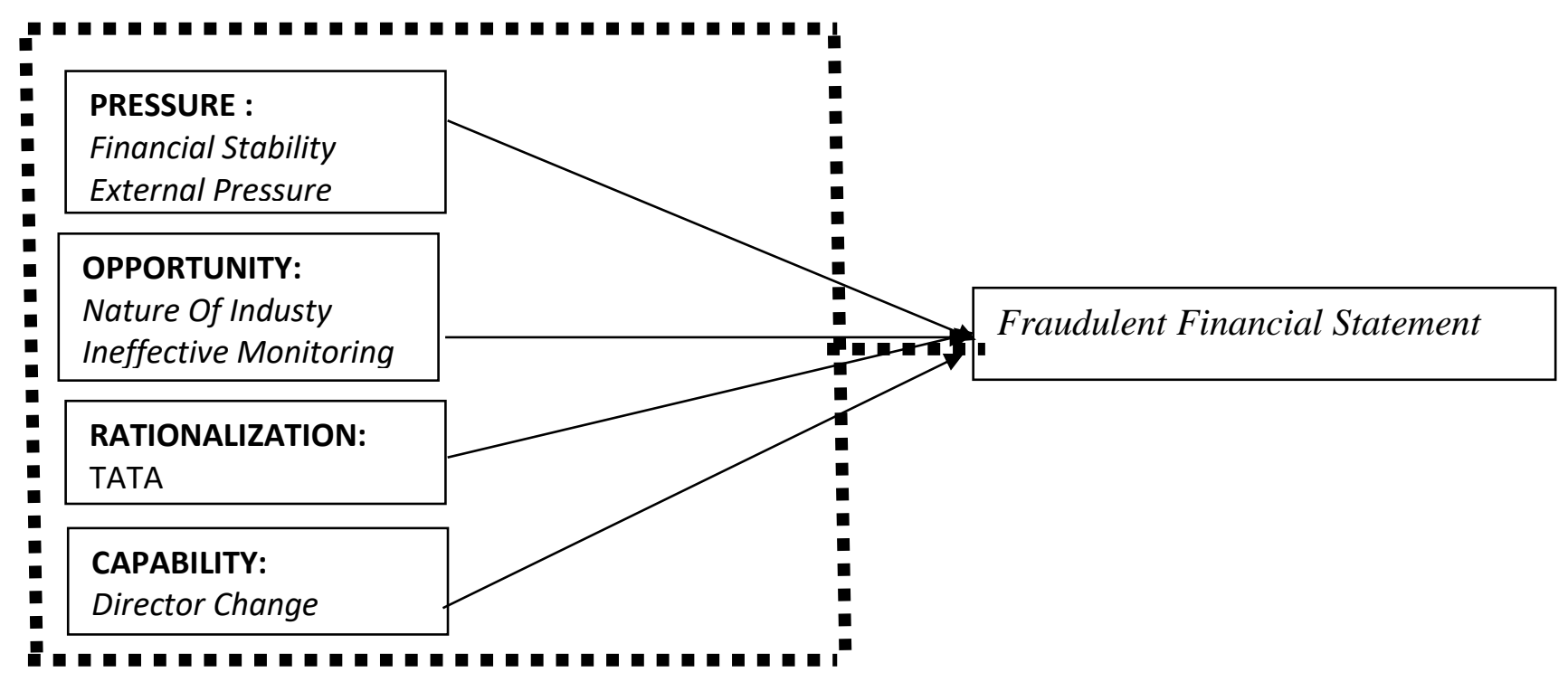

Gambar 1. Model Penelitian

\section{Kerangka Pemikiran}

Hipotesis dari kerangka pemikiran yang dibangun di gambar 1 diatas adalah sebagai berikut:

$\mathrm{H}_{1}$ : Financial Stability (FS) Berpengaruh Signifikan Untuk Mendeteksi Fraudulent Financial Statement.

$\mathrm{H}_{2}$ : External Pressure (EP) Berpengaruh Signifikan Untuk Mendeteksi Fraudulent Financial Statement.

$\mathrm{H}_{3}$ : $\quad$ Nature of Industry (NI) Berpengaruh Signifikan Untuk Mendeteksi Fraudulent Financial Statement.

$\mathrm{H}_{4}$ : Ineffective Monitoring (IM) Berpengaruh Signifikan Untuk Mendeteksi Fraudulent Financial Statement.

$\mathrm{H}_{5}$ : Rationalitation (TATA) Berpengaruh Signifikan Untuk Mendeteksi Fraudulent Financial Statement.

$\mathrm{H}_{6}$ : Capability (Dchange) Berpengaruh Signifikan Untuk Mendeteksi Fraudulent Financial Statement.

\section{METODE PENELITIAN}

Populasi dalam penelitian ini adalah seluruh perusahaan manufaktur yang terdaftar di Bursa Efek Indonesia (BEI). Sampel penelitian menggunakan metode purposive sampling, Kriteria ditentukan adalah sebagai berikut: 1. Perusahaan manufaktur yang berturut-turut terdaftar di Bursa Efek Indonesia selama periode 2014-2016. 2. Perusahaan manufaktur yang menerbitkan laporan keuangan tahunan dan telah diaudit oleh auditor independen. 3. Perusahaan yang 
menggunakan mata uang Rupiah beruturut-turut selama periode 2014-2016. Pengujian pada penelitian ini menggunakan software Eviews 10

Variabel operasional dalam penelitian ini terdiri dari Agrow, Leverage, RPT, IM, TATA, Dchange, dan Fraudulent Financial Statement sebagai variabel dependen.

Tabel 1 Rincian Rumus Variabel Independen

\begin{tabular}{|c|c|c|}
\hline No. & Nama Variabel & Rumus \\
\hline 1. & Fraud Diamond & Beneish M-Model \\
\hline 2. & Pressure & $\begin{array}{c}\text { AGROW }=(\text { Total Aset }(t)-\text { Total Aset }(t-1)) / \text { Total } \\
\text { Aset }(t-1)\end{array}$ \\
\hline 3. & Pressure & LEV = Total Debt $/$ Total Asset \\
\hline 4. & Oppourtunity & $\begin{array}{c}\text { RPT }=\text { Total Piutang Usaha Hubungan Istimewa / Total } \\
\text { PiutangUsaha Keseluruhan Perusahaa }\end{array}$ \\
\hline 5. & Oppourtunity & $\begin{array}{c}\text { IM = Jumlah Dewan Komisaris Independen / Jumlah } \\
\text { Total Dewan Komisaris }\end{array}$ \\
\hline 6. & Rationalization & $\begin{array}{l}\text { (Net Income from Continuing Operation }(t)- \\
\text { Cash Flows from Operating) / Total Aset }(t)\end{array}$ \\
\hline 7. & Capability & Jumlah pergantian dewan direksi \\
\hline
\end{tabular}

\section{HASIL DAN PEMBAHASAN}

\begin{tabular}{|c|c|c|c|c|}
\hline Variable & Coefficient & Std. Error & t-Statistic & Prob. \\
\hline c & -2.433039 & 0.176560 & -13.78021 & 0.0000 \\
\hline AGROW & 1.145947 & 0.272481 & 4.205604 & 0.0001 \\
\hline DEBT & 0.013698 & 0.036031 & 0.380160 & 0.7051 \\
\hline $\mathrm{RPT}$ & 0.025538 & 0.124204 & 0.205611 & 0.8377 \\
\hline IM & -0.035750 & 0.375695 & -0.095158 & 0.9245 \\
\hline TATA & 5.218695 & 0.460783 & 11.32571 & 0.0000 \\
\hline DCHANGE & -0.035769 & 0.044883 & -0.796940 & 0.4284 \\
\hline R-squared & 0.727219 & \multicolumn{2}{|c|}{ Mean dependent var } & -2.025352 \\
\hline Adjusted R-squared & 0.701645 & \multicolumn{2}{|c|}{ S.D. dependent var } & 0.504754 \\
\hline S.E. of regression & 0.275706 & \multicolumn{2}{|c|}{ Akaike info criterion } & 0.354423 \\
\hline Sum squared resid & 4.864882 & \multicolumn{2}{|c|}{ Schwarz criterion } & 0.577504 \\
\hline Log likelihood & -5.582009 & \multicolumn{2}{|c|}{ Hannan-Quinn criter. } & 0.443135 \\
\hline F-statistic & 28.43669 & \multicolumn{2}{|c|}{ Durbin-Watson stat } & 1.743986 \\
\hline Prob(F-statistic) & 0.000000 & & & \\
\hline
\end{tabular}

\section{Uji Koefisien Determinasi}

Berdasarkan tabel diatas yang diolah menggunakan eviews bahwa nilai Adjusted $R$ Square adalah sebesar 0,701645. Hal ini menunjukkan bahwa variabel Agrow, Debt, RPT, IM, TATA, Dchange dapat menjelaskan variabel independen sebesar 70,16\%, sedangkan $29,84 \%$, dijelaskan oleh variabel lain yang tidak termasuk kedalam penelitian ini seperti Auditor Change, ROA (Susanto 2014), Ownership (Kartika, 2012), Salta (Alamanda, 2014), Kualitas Audit (Haribowo, 2013) . 


\section{Uji Statistik t}

- Nilai prob t hitung (prob) untuk Financial Stbaility (FS) adalah sebesar 0.0001 >0.05, maka Ha1 diterima. Hal ini berarti variabel FS berpengaruh signifikan terhadap FFR.

- Nilai prob t hitung (prob) untuk External Pressure (EP) adalah sebesar $0.7051>0.05$, maka Ha2 ditolak. Hal ini berarti variabel EP tidak berpengaruh signifikan terhadap FFR.

- Nilai prob t hitung (prob) untuk Nature of Industry (NI) adalah sebesar 0.8377>0.05, maka Ha3 ditolak. Hal ini berarti variabel NI tidak berpengaruh signifikan terhadap FFR.

- Nilai prob t hitung (prob) untuk Ineffective Monitoring (IM) adalah sebesar 0.9245 > 0.05, maka Ha4 ditolak. Hal ini berarti variabel IM tidak berpengaruh signifikan terhadap FFR.

- Nilai prob t hitung (prob) untuk Rationalization (TATA) adalah sebesar $0.0000>0.05$, maka Ha5 diterima. Hal ini berarti variabel TATA berpengaruh signifikan terhadap FFR.

- Nilai prob t hitung (prob) untuk Capability (Dchange) adalah sebesar 0.4284 >0.05, maka Ha6 ditolak. Hal ini berarti variabel Dchange tidak berpengaruh signifikan terhadap FFR.

\section{Uji Statistik F}

Berdasarkan data yang diolah menggunakan eviews bahwa nilai $\mathrm{F}$ sebesar 28.43669 dengan prob (f-statistic) di bawah 0.05 , sebesar 0,000. Kesimpulan hasil penelitian Ha7 diterima. Hal ini menunjukkan bahwa variabel Agrow, Debt, RPT, IM, TATA, Dchange secara simultan berpengaruh terhadap FFR.

\section{KESIMPULAN DAN SARAN}

1. Hal diterima. Hal ini menjelaskan bahwa Agrow memilik pengaruh positif terhadap fraudulent financial statement. Mempertahankan laporan keuangan yang stabil dapat memberikan tekanan bagi para manager dari atasannya. Bonus yang didapatkannya atas hal tersebut dapat dijadikan acuan bagi manajer untuk melakukan kecurangan salah satunya dengan melakukan manipulasi laporan keuangan di area pendapatan.

2. Ha2 ditolak. Hal ini menjelaskan bahwa Debt memiliki pengaruh positif terhadap fraudulent financial statement namun tidak berpengaruh signifikan. External pressure adalah tekanan yang berlebihan bagi manajemen untuk memenuhi persyaratan atau harapan dari pihak ketiga. Salah satu tekanan dapat terjadi dari pihak eksternal terutama dari kreditor, ketidakmampuan perusahaan membayar hutangnya membuat perusahaan sulit untuk mendapatkan pendanaan. Disisi lain perusahaan diwajibkan untuk melunasi seluruh hutangnya kepada kreditor. Tekanan yang berlebihan dari pihak kreditor dalam melunasi hutang jatuh temponya membuat manajer memanipulasi laporan keuangan khususnya bagian profitabilitas yang nantinya dapat menarik pihak investor untuk menanamkan modalnya keperusahaan.

3. Ha3 ditolak. Hal ini menjelaskan bahwa RPT memiliki pengaruh positif terhadap fraudulent financial statement namun tidak signifikan. Resiko inheren menjadi tinggi ketika pihak perusahaan melakukan transaksi dengan anaknya (related parties) dikarenakan peraturan serta keterlibatan manajemen yang tinggi dapat membuat keputusan yang secara subjektif terkait transaksi yang terjadi. Dikhawatirkan salah saji material menjadi tinggi sehingga menimbulan transaksi yang berpengaruh signifikan dalam pemberian informasi pada laporan keuangan hal ini menjadi salah satu alasan karena rentan terhadap manipulasi oleh manajemen.

4. Ha4 ditolak. Hal ini menjelaskan bahwa IM memiliki pengaruh negatif terhadap fraudulent financial statement namun tidak signifikan. Pengawasan baik secara 
independen tidak cukup hanya dari komisari independen namun internal kontrol yang direview secara bersama-sama dan dapat dilaksanakan seefektif mungkin dapat mencegah seseorang melakukan fraud khususnya pada transaksi keuangan. Internal control yang efektif akan memberikan jaminan dalam mencapai tujuan organisasi dan merupakan suatu ukuran dari keamanan internal organisasi. Mencapai tujuan struktur pengendalian intern yang efektif, maka manager harus dapat memahami komponen dari COSO sehingga semakin tinggi internal control maka akan semakin baik juga bagi keberlangsungan kinerja operasional perusahaan.

5. Ha5 diterima. Hal ini menjelaskan bahwa TATA memiliki pengaruh positif terhadap fraudulent financial statement. Total akrual merupakan besaran yang telah ditentukan oleh manajer sehingga dapat memberikan peluang untuk melakukan manipulasi apabila kebijakan akrual didalam perusahaan berbeda dengan tahun sebelumnya.

6. Ha6 ditolak. Hal ini menjelaskan bahwa Dchange memiliki pengaruh negatif terhadap fraudulent financial statement. Perubahan direksi yang dilakukan oleh perusahaan terjadi karena adanya direksi yang lebih kompatible dan dapat dipercaya untuk mencapai tujuan perusahaan dibandingkan sebelumnya sehingga pergantian direksi perlu dilakukan untuk mengambil langkah yang lebih baik bagi perusahaan. Mengenai penggantian atau pemberhentian Direksi dan Dewan Komisaris diatur dalam Pasal 105 dan Pasal 119 Undang-Undang No. 40 Tahun 2007 tentang Perseroan Terbatas ("UUPT"). Dikatakan bahwa, direksi dapat diberhentikan sewaktu - waktu berdasarkan RUPS dengan memberikan alasan dari pemberhentian.

\section{REFERENSI}

Alamanda. (2015). Pengaruh Ukuran Perusahaan, Profitabilitas, Solvabilitas dan Debt Default Terhadap Penerimaan Opini Audit Going Concern Pada Perusahaan Manufaktur Yang Terdaftar DI Bursa Efek Indonesia (BEI) Periode 2009-2013. Jurnal Akutansi Unesa .

Amara, I., Amar, A. B., \& Jarboui, A. (2013). Detection of Fraud in Financial Statements: French Companies as a Case Study. International Journal of Academic Research in Business and Social Sciences, Vol. 3, No. 5 ISSN: 2222-6990.

American Institute of Certified Public Accountants (AICPA). (2002). SAS No. 99 Consideration of Fraud in a Financial Statement Audit, Statement on Auditing Standard No. 99. New York: AICPA.

Annisya, M., Lindrianasari, \& Asmaranti, Y. (2016). Pendeteksian Kecurangan Laporan Keuangan Menggunakan Fraud Diamond. "Jurnal Bisnis dan Ekonomi (JBE), 9 ISSN: 1412-3126 Vol. 23, No. 1 , Hal. $72-8$.

Aprillia, Cicilia, O., \& Sergius, R. P. (2015). The Effectiviness of Fraud Triangle On Detecting Fraudulent Financial Statement: Using Beneish Model And The Case of Special Companies. Jurnal Riset Akuntansi dan Keuangan Vol.3 .

Arista, D. (2012). Analisis Faktor - faktor Yang Mempengaruhi Return Saham (Kasus pada Perusahaan Manufaktur yang Go Public di BEI Periode Tahun 2005-2009). Jurnal Ilmu Managemen dan Akutansi Terapan, Vol 3 Nomor 1, 1-15.

Association of Certified Fraud Examiners (ACFE). (2017). Report to the Nations on Occupational Fraud and Abuse. USA.

Cahyono, D. (2014). Effect of Prior Audit Opinion, Audit Quality, and Factors of Its Audit Opinion Going Concern. Jember: Research Journal of Finance and Accounting Vol.5, No.24.

Darmawan, A., \& Saragih, S. O. (2017). The Impact of Auditor Quality, Financial Stability, and Financial Target for Fraudulent Financial Statement. Journal of Applied Accounting and Taxation Vol. 2, No. 1 e-ISSN: 2548-9925 , 9-14. 
Faradiza, S. A., \& Suyanto. ( 2017 ). Fraud Diamond: Pendeteksi Kecurangan Laporan Keuangan. Seminar Nasional Riset Terapan ISBN: 978-602-73672-1-0 .

Ghozali, I. (2012). Aplikasi Analisis Multivariate Dengan Program IBM SPSS 20 . Semarang: Badan Penerbit Universitas Diponegoro.

Hanifa, S. I., \& Laksito, H. (2015). Pengaruh Fraud Indicators Terhadap Fraudulent Financial Statement : Studi Empiris Pada Perusahaan Yang Listed di Bursa Efek Indonesia (BEI) Thaun 2008-2013. Diponogoro Journal of Accounting Volume 04, Nomor 04, ISSN (Online): 2337-3806, 1-15.

Haribowo, I. (2013). Analisis Perbandingan Pengaruh Kualitas Audit, Likuiditas, Solvabilitas, Profitabilitas Terhadap Opini Audit Going Concern (Studi Perbankan Syariah Di Asia). ISSN : 1693-4482 STAR - Study \& Accounting Reseach | Vol X, No. 3 , 51-67.

Haryono, M. E. (2017). Analisis Fraud Triangle Dalam Mendeteksi Financial Statement Fraud. $U M S E T D-d b$.

Haryono, S. (2015). Struktur Kepemilikan Dalam Bingkai Teori Keagenan. Jurnal Akutansi \& Bisnis Vol 5 (1), 63-71.

Hery. (2016). Auditing dan Asurans Pemeriksaan Akutansi Berebasis Standar Audit International. Jakarta: PT Grasindo.

Ikatan Akuntansi Indonesia (IAI). (2009). Pernyataan Standar Akutansi Keuangan (PSAK) No 1: Penyajian Laporan Keuangan . Jakarta: IAI.

Inayanti, S. N., \& Sukirman. (2016). The Effect of Factors in Fraud Diamond Perspective on Fraudulent Financial. Accounting Analysis Journal 5, 155 - 162 .

Indarto, S. L., \& Ghozali, I. (2016). Fraud Diamond : Detection Analysis On The Fraudulent Financial Report. Risk Governance \& Control: Financial Market \& Institution Volume 6, Issue 4, 114 - 123.

Jefri, R., \& Mediaty. (2014). Pendekteksian Kecurangan (Fraud) Laporan Keuangan. Jurnal Akutansi ISSN 2339-1502 Vol. 01 No. 02, 56-64.

Junaidi, Triyatmi, C. S., \& Nurdiono. (2012). Financial And Non Financial Factors On Going Concern Opinion. Journal The WINNERS, Vol. 13 No. 2, September 2012 , 135-146.

Kartika, A. (2012). Pengaruh Kondisi Keuangan dan Non Keuangan Terhadap Penerimaan Opini Going Concern Pada Perusahaan Manufaktur di BEI. Dinamika Akuntansi, Keuangan dan Perbankan, Vol. 1, No. 1, 25-40.

Krissindiastuti, M., \& Rasmini, N. K. (2016). Faktor-Faktor Yang Mempengaruhi Opini Audit Going Concern. E-Jurnal Akuntansi Universitas Udayana, 451-481.

Kusumaningsih, K. U., \& Wirajaya, I. G. (2017). Faktor-Faktor Yang Mempengaruhi Tindak Kecurangan di Perusahaan Perbankan . ISSN: 2302-8556, E-Jurnal Akuntansi Universitas Udayana, Vol.19.3. , 1832-1860.

Kusumawardhani, P. (2013). Deteksi Financial Statement Fraud Dengan Analisis Fraud Triangle Pada Perusahaan Perbankan Yang Terdaftar di BEI. JURNAL AKUNTANSI UNESA | Vol 1, No 3 .

Mahenthiran, S. (2014 ). Determinants of Fraudulent Financial Reporting: Evidence from Malaysia. Jurnal Pengurusan 42,103 - 117.

Manurung, D. T., \& Hadian, N. (2013). Detection Fraud of Financial Statement with Fraud Triangle. International Business Research ISBN: 978-1-922069-36-8 .

Manurung, D. T., \& Hardika, A. L. (2015). Analysis of factors that influence financial statement fraud in the perspective fraud diamond: Empirical study on banking companies listed on the Indonesia Stock Exchange year 2012 to 2014. International Conference on Accounting Studies (ICAS) .

Omar, N., \& Johari, Z. A. (2017). Predicting fraudulent financial reporting using artificial neural network. Journal of Financial Crime, Vol. 24 Issue: 2 , 362-387. 
Omoye, A. S., \& Eragbhe, E. (2014). Accounting Ratios and False Financial Statements Detection: Evidence from Nigerian Quoted Companies. International Journal of Business and Social Science Vol. 5, No. 7(1).

Pudjiastuti, R., \& Untara, D. (2012). Analisis Faktor-Faktor Yang Mempengaruhi Auditor Dalam Pemberian Opini Going Concern. ISSN-1411 - 3880, 15-37.

Repousis, S. (2016). Using Beneish Model To Detect Corporate Financial Statement Fraud In Greece. Emerald Insight Journal of Financial Crime, Vol. 23 Issue: 4, 1063-1073.

Rose, Westerfield, \& Jordan. (2012). Fundamentals of Corporate FInance. New York: McGrawHill.

Ryadi, P. R., Irianto , G., \& Roekhudin . (2017). Fraud Diamond and Management Fraudulent Act Analysis:. The International Journal Of Humanities \& Social Studies (ISSN 2321 9203), 29 - 33 .

Scott, W. R. (2000). Setiap perusahaan berharap dapat menyajikan laporan keuangan yang baik bagi para pengguna laporan keuangan. Jika laporan keuangan perusahaan dinilai sehat maka akan memberikan daya tarik bagi investor untuk menanamkan modalnya kepada perusahaan, sehingga . Canada: Prentice Hall.

Sekaran, U., \& Bougie, R. (2010). Research Method For Business: A Skill-Building Approach, Fifth Edition. Great Britain: John Wiley \& Sons Limited.

Sihombing, K. S., \& Rahardjo, S. N. (2014). Analisis Fraud Diamond Dalam Mendeteksi Financial Statement Fraud : Studi Empiris Pada Perusahaan Manufaktur Yang Terdaftar di Bursa Efek Indonesia. Diponegoro Journal of Accounting Volume 03, Nomor 02, , 112.

Singleton, T. W., \& Singleton, A. J. (2010). Fraud Auditing And Forensic Accounting Forth Edition. Hoboken, New Jersey: John Wiley \& Sons, Inc.,.

Skousen, C. J., Smith, K. R., \& Wright, C. J. (2009). Setiap perusahaan berharap dapat menyajikan laporan keuangan yang baik bagi para pengguna laporan keuangan. Jika laporan keuangan perusahaan dinilai sehat maka akan memberikan daya tarik bagi investor untuk menanamkan modalnya kepada perusahaan, sehingga . Emerald insgiht, Vol. 13: 1-39.

Sunardi , \& Amin, N. (2018). Fraud detection of financial statement by using fraud diamond perspective. International Journal of Development and Sustainability, 878 - 891.

Susanto, Y. K. (2009). Faktor-Faktor Yang Mempengaruhi Penerimaan Opini Audit Going Concern Pada Perusahaan Publik Sektor Manufaktur. Jurnal Bisnis dan Akutansi Vol 11, No. 3 , 155-173.

Suwardjono. (2017). Teori Akutansi Perekayasaan Pelaporan Keuangan Edisi Ketiga . Yogyakarta: BPFE-Yogyakarta.

Suyanto. (2009, ). Fraudulent Financial Statement Evidence From Statement on Auditing Standard No 99. Gadjah Mada International Journal of Business, Vol. 11, No. 1 , $117-$ 144.

Wolfe, D. T., \& Hermanson, D. R. (2014). The Fraud Diamond: Considering the Four Elements of Fraud. The CPA Journal: , 38-42. 